\title{
Proceeding
}

10th INSHS International Christmas Sport Scientific Conference, 4-5 December 2015. International Network of Sport and Health

\section{The influence of strength abilities on sports performance in climbing}

JAN DOŠLA , JAN MEŠKO

Faculty of Sports Studies, Masaryk University, Brno, Czech Republic

\begin{abstract}
The article discusses the influence of strength abilities on performance in climbing. Strength abilities were measured using two motor tests, test of dynamometry and pull-up hang test. We also measured selected anthropometric parameters (height, weight, body fat percentage and somatotype components - endomorphic, mesomorphic, ectomorphic). During the research a total of 46 persons have been measured; these were divided into three groups - performance climbers, recreational climbers and non-climbers. Only men have been included in the test. Statistically significant differences were found in parameters "pull-up hang" and "body fat percentage". No statistically significant differences between other parameters have been found. Average somatotype of the performance climbers was 2.03-4.87-2.98 which corresponds to the ectomorphic mesomorphy. Key words: CLIMBING, STRENGTH ABILITIES, DYNAMOMETRY, PULL-UP HANG, SOMATOTYPE, BODY FAT.
\end{abstract}

Corresponding author. Údolní 3, Brno 602 00, Czech Republic.

E-mail: dosla@fsps.muni.cz

10th INSHS International Christmas Sport Scientific Conference, 4-5 December 2015. International Network of Sport and Health Science. Szombathely, Hungary.

JOURNAL OF HUMAN SPORT \& EXERCISE ISSN 1988-5202

(C) Faculty of Education. University of Alicante

doi:10.14198/jhse.2016.11.Proc1.06 


\section{INTRODUCTION}

Sport climbing has been experiencing a significant boom recently (Panáčková, Baláš, \& Bunc, 2012; Schlegel, Fialová, Ulrichová, \& Frainšic, 2012; Vomáčko \& Boštíková, 2008). In Brno, the second largest city in the Czech Republic, three large climbing were built in the last two years which in effect doubled the number of climbing facilities. Together with the growing popularity of sport climbing a need has arisen for an extensive examination of climbing performance. It is also essential to determine the key components of climbing performance which has already been investigated by many scholars (Grant, Hynes, Whittaker \& Aitchison, 1996; Mermier, Janot, Parker \& Swan, 2000; Grant, Hasler, Davies, Aitchison, Wilson \& Whittaker, 2001; Baláš, Strejcová \& Hrdličková, 2008; Vomáčko, 2009). The above-mentioned authors all focused on anthropometric and fitness characteristics of sport climbers of various levels. Of all fitness abilities they placed particular emphasis on strength abilities. A significant role in the structure of climbing performance is also played by individual anthropometric parameters which are, particularly in the area of top and performance levels, essential in an effort to achieve the best performance.

Sport climbing requires well-developed strength abilities. Of particular importance are the maximum and endurance strength of arms and the upper part of body and the maximum static strength of finger flexors. (Heller, 1996). Specific methods for the development of strength abilities for the purposes of sport climbing has been researched by Tefelner (2012) who recommends, besides gaining strength with the actual climbing and bouldering, dynamic and static exercises on the horizontal bar, static hangs on edges or holds of various shapes, exercises on ladder and climbing the rope, dynamic exercises on a special edge board-campus board and other exercises e.g. in a gym or using less traditional exercises aids (TRX, system board, etc.). The differences in strength abilities between climbers and non-climbers are usually not significant. Grant, Hynes, Whittaker, \& Aitchison (1996) investigated a set of ten performance climbers (level 6+ UIAA or higher), ten recreational climbers and ten non-climbers and observed significant differences between the groups in the values of maximum static strength left hand grip, the thumb and index finger grip strength in both hands and the strength of two and four fingers in both hands in an open grip. In addition, they also discovered significant differences in variables "pull-up hang" and "repeated pull-ups". Similar results have been observed by Baláš, Strejcová \& Hrdličková (2008) who compared groups of performance and recreational male and female climbers. The scholars stated that performance climbers of both sexes show greater absolute and relative strength of grip and longer pull-up hang. MacLeod, Sutherland, Buntin, Whittaker, Aitchison, Watts, ... \& Grant (2007) discovered significant differences between climbers and non-climbers in maximum and relative volitional four-finger contraction in an open grip (measured by a specially designed apparatus). Some of these research results are summed up in tables 1 and 2 . 
Table 1. The results of the most common strength ability tests - men (values marked * were measured on the right hand, in others the dominant hand was measured)

\begin{tabular}{|l|c|c|c|c|c|c|}
\hline & N & $\begin{array}{c}\text { Performance } \\
\text { (UIAA) }\end{array}$ & $\begin{array}{c}\text { Hand } \\
\text { dynamome } \\
\text { try (N) }\end{array}$ & $\begin{array}{c}\text { Relative hand } \\
\text { dynamometry } \\
\text { (N/kg TH) }\end{array}$ & $\begin{array}{c}\text { Pull-up } \\
\text { hang (s) }\end{array}$ & Pull-ups (n) \\
\hline Baláš et al. (2012) & 11 & $9+$ až 11+ & & $7,9 \pm 0,7$ & $84,5 \pm 23,2$ & \\
\hline Šefl (2009) & 12 & 7 až 10 & $502 \pm 72^{*}$ & & $64,9 \pm 22,6$ & $18,7 \pm 6,4$ \\
\hline Mermier et al. (2000) & 24 & $6-$ až 10- & & $6,5 \pm 1,4$ & $51,8 \pm 14,6$ & \\
\hline Baláš et al. (2012) & 38 & $7+$ až 9 & & $7,2 \pm 0,9$ & $64,2 \pm 19,1$ & \\
\hline Baláš et al. (2008) & 12 & 7 až 9 & $532 \pm 74$ & $7,2 \pm 1,2$ & $58,0 \pm 17,4$ & \\
\hline Grant et al. (1996) & 10 & $>6+$ & $532 \pm 23^{*}$ & & $53,1 \pm 13,2$ & $16,2 \pm 7,2$ \\
\hline Grant et al. (1996) & 10 & $<6+$ & $472 \pm 23^{*}$ & & $31,4 \pm 9,0$ & $3,0 \pm 9,0$ \\
\hline Baláš et al. (2008) & 33 & 3 až 6 & $453 \pm 86$ & $5,8 \pm 0,1$ & $34,9 \pm 21,3$ & \\
\hline
\end{tabular}

Table 2. The results of the most common strength ability tests - women (values marked * were measured on the right hand, in others the dominant hand was measured)

\begin{tabular}{|l|c|c|c|c|c|c|}
\hline & $\mathrm{N}$ & $\begin{array}{c}\text { Performance } \\
\text { (UIAA) }\end{array}$ & $\begin{array}{c}\text { Hand } \\
\text { dynamome } \\
\text { try (N) }\end{array}$ & $\begin{array}{c}\text { Relative hand } \\
\text { dynamometry } \\
\text { (N/kg TH) }\end{array}$ & $\begin{array}{c}\text { Pull-up } \\
\text { hang (s) }\end{array}$ & Pull-ups (n) \\
\hline Baláš et al. (2012) & 3 & $9+$ až 11+ & & $7,2 \pm 0,7$ & $68.9 \pm 6.4$ & \\
\hline Baláš et al. (2012) & 12 & $7+$ až 9 & & $6,0 \pm 0,6$ & $59.4 \pm 12.4$ & \\
\hline Baláš et al. (2008) & 3 & 7 až 9 & $321 \pm 57$ & $5,5 \pm 0,6$ & $44,7 \pm 22,2$ & \\
\hline Mermier et al. (2000) & 20 & $5-$ až 9- & & $4,9 \pm 1,0$ & $25,1 \pm 14,4$ & \\
\hline Grant et al. (2001) & 10 & $>5+$ & $338 \pm 12^{*}$ & & $27,5 \pm 19,4$ & $2,1 \pm 3,0$ \\
\hline Baláš et al. (2008) & 20 & $3 \mathrm{až6}$ & $275 \pm 56$ & $4,4 \pm 0,8$ & $14,9 \pm 14,8$ & \\
\hline Grant et al. (2001) & 10 & $<5+$ & $289 \pm 10^{*}$ & & $13,7 \pm 8,1$ & $0,2 \pm 0,7$ \\
\hline
\end{tabular}

It is also of great importance to determine the somatotype of climbers. The following authors were concerned with the relationship between somatotype and sport performance: Štěpnička, Chytráčková (in Riegerová, Pridalová \& Ulbrichová, 2006), or Pavlík (2003). While the mesomorpic components are the most important for general motor abilities, higher level of endomorphic component has generally negative influence on general motor performance. However, a suitable somatotype does not mean an automatic success in a given sport. It is merely one of the factors which contribute to the success. Low level of endomorphic component is essential for high performance in sport climbing and climbers should not have a significantly high value of mesomorpic component. The ideal somatotype for a sport climber may be set as mesomorphic ectomorph or a balanced meso-ectomorph. Also, top and performance climbers, unlike team sport players, will probably not show a significant variability of somatotype.

\section{MATERIAL AND METHODS}

A total of 46 men in the ages of 18 to 40 participated in this research. The tested persons have been chosen using the method of stratified sampling. Only the climbers attending climbing walls in Brno, Broumov and Police nad Metuji were selected for this research. Probandi to the non-climber category were selected from 
the students of the Faculty of Education and the Faculty of Sports Studies of Masaryk University in Brno. Those selected have been divided into three groups based on their climbing skills - performance climbers, recreational climbers and non-climbers. Only those climbers who have climbed, in the last ten months, a route of grade 7 or higher UIAA using the RP or PP styles have been designated performance climbers. Recreational climbers were those who have more than one year climbing experience but are unable to climb a route of grade 7 or higher UIAA using RP or PP styles. The last category included those who are physically active (i.e. doing some sport) but refrain from doing any type of climbing. All participants have been informed of the methods and objectives of the research and agreed to take part in it. The basic details of the persons tested have been acquired using a short 7-point non-standardized questionnaire. The details obtained included age, climbing experience, frequency of climbing, specialization in climbing disciplines, the grade of the most difficult route climbed using Top Rope or Red Point (or Pink Point) styles in the last ten months and the type and frequency of other sport activities. The information of the research sample are included in table 3.

Table 3. Basic details of the persons tested (average \pm standard deviation)

\begin{tabular}{|l|l|l|l|}
\hline & $\begin{array}{l}\text { Competitive } \\
\text { climbers } \\
(\mathbf{n}=\mathbf{1 6})\end{array}$ & $\begin{array}{l}\text { Recreation } \\
\text { al climber s } \\
(\mathbf{n}=\mathbf{1 5})\end{array}$ & $\begin{array}{l}\text { Non- } \\
\text { climbers } \\
(\mathbf{n}=\mathbf{1 5})\end{array}$ \\
\hline Age (years) & $29,1 \pm 7,1$ & $25,5 \pm 4,9$ & $23,7 \pm 1,6$ \\
\hline $\begin{array}{l}\text { Length of climbing practice } \\
\text { (years) }\end{array}$ & $7,9 \pm 7,5$ & $5,6 \pm 5,2$ & - \\
\hline $\begin{array}{l}\text { Climbing frequency (per } \\
\text { week) }\end{array}$ & $2,0 \pm 0,7$ & $1,4 \pm 0,6$ & - \\
\hline $\begin{array}{l}\text { Maximum performance Top } \\
\text { Rope }\end{array}$ & 8 UIAA & $6 / 6+$ UIAA & - \\
\hline $\begin{array}{l}\text { Maximum performance RP } \\
\text { (PP) }\end{array}$ & $8-18$ UIAA & $6-16$ UIAA & - \\
\hline $\begin{array}{l}\text { Frequency of other sport } \\
\text { activities (per week) }\end{array}$ & $1,9 \pm 2,4$ & $2,6 \pm 2,6$ & $3,8 \pm 1,8$ \\
\hline
\end{tabular}

Strength abilities were measured using two tests, the test of dynamometry and pull-up hang test. The hand dynamometry was used to determine the maximum strength of hand grip (maximum static strength of finger flexors). Digital analyzer MIE (Medical Research Ltd.) have been used for measurement. The tested persons performed two attempts on each hand, the better attempt was counted. Pull-up hang test was used to measure the endurance level of static strength of arm flexors and shoulder girdle. The test was carried out on an overhand grip in shoulder width with chin above the bar. Handheld stopwatch that count by a tenth of a second the attempts. The attempt was over when the tested person's chin touched the bar or chin descended below the bar.

MS Excel 2010 a STATISTICA 12 have been used for statistical processing of numerical data which were acquired by the above-mentioned methods. First, a basic descriptive statistics was carried out together with the determination of averages and standard deviation of individual variables for each group. Then, to compare the results of all three groups, the analysis of variance (ANOVA) has been used with the level of statistical significance $a=0,05$. To ensure the basic assumption for a parametric ANOVA, Levene's test of the homogeneity of variances was carried out first. For variables which showed non-homogeneous 
variances, a non-parametric Kruskal-Wallis test was performed. Those variables which showed a significant difference, underwent a multiple comparison using Bonferroni post hoc test (Zvárová, 1998).

As the extent of the analyzed sample plays an important role for the calculation of $p$-values and the overall determination of statistical significance, we have decided to amend this study with an evaluation of the level of effect size using the coefficients of effect size associated with specific types of statistical tests. This concerns the coefficient $\omega^{2}$ which may be calculated from the value of the tested criterion of the analysis of variances. The variables which show middle or high effect, Cohen coefficient $d$ has been used which compares pairs of averages related to standard deviation and the extent of the sample (Sigmund \& Sigmundová, 2010). It should be apparent from the results between which groups there is a factually significant difference.

To determine the amount of fat, caliperation method of Pařizková (1962) has been used. This involves the measurement of the thickness of ten skinfolds using caliper of Best type with the accuracy of 0,5 mm. All skin folds have been measured on the right part of the body. A regression equation has been used to calculate body fat percentage (Riegrová, Přidalová, Ulbrichová, 2006). Somatotype has been identified based on Carter and Heath by measuring ten anthropometric parameters. (Carter, Heathová in Grasgruber, Cacek, 2008).

\section{RESULTS}

First, we examined the relationships between the level of climbing skills and individual anthropometric parameters. The measured values have been summed up in table 4. Performance climbers have, when compared to recreational climbers, lower weight (but of similar heights) and also lower percentage of body fat. Non-climbers are much heavier but only a little higher than the other two groups.

Table 4. Selected anthropometric parameters (average \pm standard deviation)

\begin{tabular}{|l|c|c|c|}
\hline & $\begin{array}{c}\text { Competitive } \\
\text { climbers } \\
(\mathbf{n}=\mathbf{1 6})\end{array}$ & $\begin{array}{c}\text { Recreational } \\
\text { climbers }(\mathbf{n}=\mathbf{1 5})\end{array}$ & $\begin{array}{c}\text { Non-climber s } \\
(\mathbf{n}=\mathbf{1 5})\end{array}$ \\
\hline Height (cm) & $179,0 \pm 9,3$ & $179,6 \pm 5,7$ & $182,1 \pm 7,5$ \\
\hline Weight (kg) & $71,9 \pm 8,1$ & $74,2 \pm 9,4$ & $79,0 \pm 7,5$ \\
\hline $\begin{array}{l}\text { Percentage of body fat } \\
(\%)\end{array}$ & $10,9 \pm 2,9$ & $13,9 \pm 3,8$ & $14,4 \pm 4,5$ \\
\hline Endomorphy & $2,0 \pm 0,6$ & $2,7 \pm 0,9$ & $2,9 \pm 1,2$ \\
\hline Mezomorphy & $4,9 \pm 0,9$ & $4,8 \pm 0,7$ & $5,1 \pm 1,1$ \\
\hline Ectomorphy & $3,0 \pm 1,0$ & $2,8 \pm 1,0$ & $2,6 \pm 1,1$ \\
\hline
\end{tabular}


Table 5. Levene's test of homogeneity of variances

\begin{tabular}{|c|c|c|c|c|}
\hline & effect & deviation & F & p \\
\hline Height $(\mathrm{cm})$ & 20,04602 & 23,06941 & 0,86894 & 0,42663 \\
\hline Weight (kg) & 23,99807 & 25,58672 & 0,93791 & 0,39931 \\
\hline $\begin{array}{l}\text { Percentage of body } \\
\text { fat }(\%)\end{array}$ & 8,10714 & 4,44718 & 299 & 7381 \\
\hline Endomorphy & 1,16318 & 0,28851 & 4,03172 & 0,02484 \\
\hline Mezomorphy & 0,56023 & 0,29292 & 1,91255 & 0,16006 \\
\hline Ectomorphy & 0,09344 & 0,40468 & 0,23090 & 0,79479 \\
\hline
\end{tabular}

It is apparent from the results of the Levene's test (table 5) that variables "endomorphic" fail to meet the requirement of homoscedasticity and therefore we used non-parametric Kruskal-Wallis test instead of parametric ANOVA.

By analyzing variances we found out that the $p$-values of the body fat percentage variable are lower than the level of statistic significance $\alpha=0,05$ As a result, we may state with $95 \%$ certainty, for this variable, that the results of the three observed groups are statistically and significantly different. For other variables, however, no significant difference has been identified. During the verification of endomorphic variable using the Kruskal-Wallis test, the resulting $p$-value exceeded the level of statistical significance 0,05 which means that the differences between the groups are statistically insignificant.

Those variables, for which a significant difference between the groups has been identified, have been tested with Bonferroni post-hoc test. For body fat percentage (table 6), statistically significant difference has been identified only between performance climbers and non-climbers.

Table 6. Bonferroni test, Body fat percentage

\begin{tabular}{|r|r|r|r|}
\hline & Competitive & Recreationa1 & Non-clim bers \\
\hline Competitive & & 0,091749 & $\mathbf{0 , 0 3 6 9 6 9}$ \\
\hline Recreationa1 & 0,091749 & & 1,000000 \\
\hline Non-clim bers & $\mathbf{0 , 0 3 6 9 6 9}$ & 1,000000 & \\
\hline
\end{tabular}

Similar conclusions have also been reached by MacLeod, D., Sutherland, D. L., Buntin, L., Whittaker, A., Aitchison, T., Watt, I., ... \& Grant, S. (2007), who identified significant differences in body fat percentage between groups of climbers and non-climbers. An important relationship between climbing performance and body fat percentage has also been identified Baláš, Strejcová \& Hrdličková (2008).

Additionally, strength abilities have been tested using two tests - test of "dynamometry" and "pull-up hang test". The results of the strength abilities measurements are summed up in table 7 . These results have been further analyzed using ANOVA (table 8) which showed that p-values of variables in the pull-up hang test are lower than the level of statistical significance $a=0,05$. As a result, we may state with $95 \%$ certainty that the results of the three observed groups are statistically and significantly different. Using the Bonferroni post-hoc test we have identified a significant difference between performance climbers and non-climbers and also between performance and recreational climbers. 
Table 7. Results of strength abilities tests

\begin{tabular}{|l|c|c|c|}
\hline & $\begin{array}{c}\text { Competitive } \\
\text { climber s } \\
(\mathbf{n}=\mathbf{1 6})\end{array}$ & $\begin{array}{c}\text { Recreational } \\
\text { climbers } \\
(\mathbf{n}=\mathbf{1 5})\end{array}$ & $\begin{array}{c}\text { Non- } \\
\text { climber s } \\
(\mathbf{n}=\mathbf{1 5})\end{array}$ \\
\hline Dynamometry right hand (N) & $533,4 \pm 58,3$ & $523,7 \pm 78,6$ & $534,5 \pm 91,6$ \\
\hline Dynamometry left hand (N) & $505,8 \pm 70,4$ & $484,0 \pm 64,9$ & $499,9 \pm 105,3$ \\
\hline $\begin{array}{l}\text { Relative dynamometry right hand } \\
\text { (N/kg) }\end{array}$ & $7,48 \pm 1,00$ & $7,10 \pm 0,95$ & $6,79 \pm 1,13$ \\
\hline $\begin{array}{l}\text { Relative dynamometry left hand } \\
\text { (N/kg) }\end{array}$ & $7,10 \pm 1,20$ & $6,58 \pm 0,88$ & $6,32 \pm 1,16$ \\
\hline Pull-up hang (s) & $59,4 \pm 17,5$ & $41,1 \pm 11,1$ & $36,2 \pm 11,5$ \\
\hline
\end{tabular}

The last parameter measured was the somatotype of the individual climbers and the groups. The average somatotype measured for performance climbers was 2.03-4.87-2.98. This value corresponds with ectomorphic mesomorphia. The biggest differences from other groups were in the value of endomorphic component. The average somatotype for recreational climbers was 2.67-4.82-2.82. Compared to the previous group, it shows a significantly higher value of endomorphic component, approximately the same value of mesomorphic and a sligthly lower value of ectomorphic component. The average somatotype of non-climbers was 2.95-5.11-2.56 which corresponds with the endomorphic mesomorph category. Compared with the previous groups, this sample has higher average values of endomorphic and mesomorphic components and shows a lower value of ectomorphic component. Our findings fail to correspond with the findings of Polčin (2011) who in his study measured on his sample of 20 climbers the average somatotype $3,5-5,1-2,6$. He fails to mention the climbing ability of his sample; however, the difference in the endomorphic component is particularly significant.

One of the probands in our measurement was Adam Ondra who might currently be the best climbers in the world. His results are not included in the group of performance climbers but they are offered for comparison in a separate discussion. His height is $183 \mathrm{~cm}$, his weight is $66,2 \mathrm{~kg}$ and his body fat percentage is $6,6 \%$. His somatotype is 1,25-4-4,5. It is apparent that compared to other climbers he has very low endomorphic component and high ectomorphic component. Also, his body weight and body fat percentage is very low compared to other climbers. Not even mesomorphia which signifies the development of bones and muscles reaches higher than mid-values which does not prevent him from achieving remarkable climbing feats.

\section{DISCUSSION}

As far as the basic anthropometric parameters (i.e. height and weight) are concerned, our results were similar to those described in other studies. The average height of performance climbers $(179,0 \pm 9,3 \mathrm{~cm})$ was virtually the same for recreational climbers $(179,6 \pm 5,7 \mathrm{~cm})$. Non-climbers were, on average, only 3 or 2.5 centimeters higher. Even Adam Ondra is not particularly high $(183,5 \mathrm{~cm})$. In theory, higher climbers should reach higher during climbing but they would be disadvantaged by higher body weight and possibly also unsuitable level mechanism of upper limbs. The higher reach of arms brings advantage only in certain climbing steps, not in the whole spectrum of climbing routes.

The average body weight was significantly different between groups. Performance climbers $(71,9 \mathrm{~kg})$ were on average lighter then recreational climbers $(74,2 \mathrm{~kg})$ and non-climbers $(79,0 \mathrm{~kg})$. Adam Ondra's body weight is $66,2 \mathrm{~kg}$. It is understandable low body weight constitutes an advantage in a physical activity which 
is concerned with overcoming gravity. It is also important, however, to keep a sufficient percentage of active body mass. Another significant parameter is body fat percentage which has been measured using the methods of Pařízková. The average body fat percentage was 10,9 $\pm 2,9 \%$ (Ondra 6,6 \%) for performance climbers, $13,9 \pm 3,8 \%$ for recreational climbers and $14,4 \pm 4,5 \%$ for non-climbers. The difference between performance climbers and non-climbers was statistically significant $(p=0,037)$. It is apparent that body fat percentage decreases with higher performance level. Similar conclusions have been reached by MacLeod, Sutherland, Buntin, Whittaker, Aitchison, Watts, ... \& Grant (2007) and Baláš, Strejcová, \& Hrdličková (2008).

The results of dynamometry showed no differences between performance groups in static strength of hand grip. Therefore, the findings of Baláš, Strejcová, \& Hrdličková (2008), Šefl (2009), and Vomáčka, Baláše, \& Jindry (2011) that performance climbers show higher grip strength cannot be confirmed. Some differences between the groups have been identified when the results have been converted to the kilograms of body weight (performance climbers: 7,48 N/kg; recreational climbers: 7,10 N/kg; non-climbers: $6,79 \mathrm{~N} / \mathrm{kg}$ - results of the right hand). Also Ondra reached a high level of the relative strength of hand grip $(9,17 \mathrm{~N} / \mathrm{kg}$ - the right hand). This tendency, however, has not been confirmed by a statistical data analysis.

The biggest differences between the three observed groups were evident in the motor overhand pull-up test. The performance climbers in our research reached an average hang of 59,4 seconds, while recreational climbers had an average of 41,1 seconds and non-climbers 36,2 seconds which may be compared with the studies of Grant, Hynes, Whittaker, \& Aitchison (1996) and Baláš, Strejcová, \& Hrdličková (2008) who measured similar values in performance climbers. Adam Ondra's hang was 89,97 seconds which was the best result in our measurement. Both statistically and factually significant differences have been found between performance and recreational climbers $(p=0,002)$ and between performance climbers and nonclimbers $(p=0,00009)$. The results show that endurance static strength of shoulder girdle is essential. Vomáčko, Baláš, \& Jindra (2011) even consider this strength an important predictor of climbing performance and believe that it is a prerequisite of high climbing performance in the duration of at least 60 seconds. In our research, however, 5 out of 16 performance climbers failed to reached this value. We believe that the handicap of lower endurance strength may be compensated by a superb climbing technique and the selection of suitable routes, particularly those which are leaning and vertical.

\section{CONCLUSIONS}

The objective of this study was to examine the relationship between climbing performance and strength abilities. Additionally, we investigated selected anthropometric parameters. The measurement resulty show that performance climbers are of above-average height $(179 \pm 9,3 \mathrm{~cm})$ with lower body weight $(71,2 \pm 8,1$ $\mathrm{kg})$ and lover body fat percentage $(10,9 \pm 2,9 \%)$. Their average somatotype may be categorized as ectomorphic mesomorph. Compared to non-climbers, they have significantly lower value of endomorphic component. The essential component seems to be mesomorphic which was never below $3 \frac{1}{2}$ for the measured climbers. These findings should be taken into account by coaches and climbing instructors when selecting climbing talents. In performance climbing, low body weight and low body fat percentage are essential for climbing performance.

The results of the motor test show that performance climbers have higher level of static endurance strength of muscles which are involved in extension in shoulded joint ("pull-up hang test"). On the other hand, maximum and relative strength of hand grip show only minor differences. As far as maximum strength of hand grip is concerned, this parameter may not be as significant as e.g. endurance strength of grip which has also been confirmed by MacLeod, Sutherland, Buntin, Whittaker, Aitchison, Watts, ... \& Grant (2007). 
Based on the results of our testing, a specific training on a climbing or bouldering wall may be recommended which contributes to the development of the much needed fitness abilities and also improves the climbing technique. We may also recommend unspecific training methods which are focused on the strength of upper limbs. The suitable exercises might include overhand pull-ups on horizontal bar, ropoe climbing or workouts on leaning ladder.

\section{REFERENCES}

1. Baláš, J., Strejcová, B., \& Hrdličková, A. (2008). Srovnání úrovně svalové síly a tělesného složení u rekreačních a výkonnostních lezců. Česká kinantropologie, 14(3), 104-114.

2. Baláš, J., Pecha, O., Martin, A. J., \& Cochrane, D. (2012). Hand arm strength and endurance as predictors of climbing performance. European Journal of Sport Science, 12(1), $16-25$.

3. Grant, S., Hasler, T., Davies, C., Aitchison, T. C., Wilson, J., \& Whittaker, A. (2001). A comparison of the anthropometric, strength, endurance and flexibility characteristics of female elite and recreational climbers and nonclimbers. Journal of Sports Sciences, 19(7), 499-505.

4. Grant, S., Hynes, V., Whittaker, A., \& Aitchison, T. C. (1996). Anthropometric, strength, endurance and flexibility characteristics of elite and recreational climbers. Journal of Sports Sciences, 14(4), 301-309.

5. Grasgruber, P., \& Cacek, J. (2008). Sportovní geny. Brno: Computer Press.

6. Heller, J. (1996). Fyziologie tělesné zátěže II. Speciální část, 3. díl. Praha: Karolinum.

7. MacLeod, D., Sutherland, D. L., Buntin, L., Whittaker, A., Aitchison, T., Watt, I., ... \& Grant, S. (2007). Physiological determinants of climbing-specific finger endurance and sport rock climbing performance. Journal of Sports Sciences, 25(12), 1433-1443.

8. Mermier, C. M., Janot, J. M., Parker, D. L., \& Swan, J. G. (2000). Physiological and anthropometric determinants of sport climbing performance. British Journal of Sports Medicine, 34(5), 359-365.

9. Panáčková, M., Baláš, J., \& Bunc, V. (2012). Vliv profilu stěny a rychlosti lezení na energetickou náročnost lezení u skupiny rekreačních a výkonnostních lezců. Česká kinantropologie, 16(2), 124132.

10. Pařízková, J. (1962). Rozvoj aktivní hmoty a tuku u dětí a mládeže. Praha: Státní zdravotnické nakladatelství.

11. Pavlík, J. (2003). Tělesná stavba jako faktor výkonnosti sportovce. Brno: MU.

12. Polčin, M. (2011). Somatometrie horolezců. Diplomová práce. Brno: PřF MU.

13. Riegerová, J., Přidalová, M., \& Ulbrichová, M. (2006). Aplikace fyzické antropologie v tělesné výchově a sportu: (př́ručka funkční antropologie). Olomouc: Hanex.

14. Schlegel, P., Fialová, L., Ulrichová, T., \& Frainšic, M. (2012). Rozvoj vybraných motorických schopností u dětí školního věku prostřednictvím sportovního lezení. Česká kinantropologie, 16(3), 56-62.

15. Šefl, J. (2009). Posouzení závislosti fyzické zdatnosti a lezeckého výkonu ve sportovním lezení. Diplomová práce. Praha: UK FTVS.

16. Tefelner, R. (2012). Trénink sportovního lezce II. Czech Republic: Rock Art Studio.

17. Vomáčko, L. (2009). Ke struktuře výkonu ve sportovním lezení v souvislosti s obecnými a speciálními testy pohybové výkonnosti a osobnostního profilu lezce. Disertační práce. Praha: UK FTVS.

18. Vomáčko, L. \& Boštíková, S. (2008). Lezení na umělých stěnách. Praha: Grada.

19. Zvárová, J. (1998). Základy statistiky pro biomedicínské obory. Praha: Karolinum. 